Article

\title{
Ips sexdentatus Mass-Trapping: Mitigation of Its Negative Effects on Saproxylic Beetles Larger Than the Target
}

\author{
Matteo Bracalini, Francesco Croci, Emanuele Ciardi, Giulio Mannucci D, Emanuele Papucci, Giulia Gestri, \\ Riziero Tiberi and Tiziana Panzavolta *D
}

Citation: Bracalini, M.; Croci, F.;

Ciardi, E.; Mannucci, G.; Papucci, E.; Gestri, G.; Tiberi, R.; Panzavolta, T. Ips sexdentatus Mass-Trapping: Mitigation of Its Negative Effects on Saproxylic Beetles Larger Than the

Target. Forests 2021, 12, 175. https://doi.org/10.3390/f12020175

Academic Editor: Christopher Fettig Received: 5 January 2021

Accepted: 29 January 2021

Published: 3 February 2021

Publisher's Note: MDPI stays neutral with regard to jurisdictional claims in published maps and institutional affiliations.

Copyright: (C) 2021 by the authors. Licensee MDPI, Basel, Switzerland. This article is an open access article distributed under the terms and conditions of the Creative Commons Attribution (CC BY) license (https:// creativecommons.org/licenses/by/ $4.0 /)$.
Department of Agricultural, Food, Environmental and Forestry Science and Technology (DAGRI), Plant Pathology and Entomology Section, University of Florence, 50144 Florence, Italy; mbracalini@unifi.it (M.B.); checco.croci@gmail.com (F.C.); emanuele.ciardi@stud.unifi.it (E.C.); giulio.mannucci@stud.unifi.it (G.M.); emasora@live.it (E.P.); giulia.gestri@stud.unifi.it (G.G.); rtiberi@unifi.it (R.T.)

* Correspondence: tpanzavolta@unifi.it

\begin{abstract}
Research Highlights: We investigated the negative effects of bark beetle mass trapping, especially non-target catches among the target's natural enemies. Slot traps modified with mesh screen and escape windows were tested to improve their selectiveness. Background and Objectives: Two of the main natural enemies of bark beetles, Thanasimus formicarius (L.) and Temnoscheila caerulea (Olivier), are frequently trapped in high numbers in Ips sexdentatus (Böerner) pheromone traps, along with other saproxylic insects; this may lead to much larger pest populations in the successive 420 beetle generations. From 2016-2019, during I. sexdentatus mass-trapping in a pine forest of Tuscany (Italy), non-target catches were tallied. Trap modifications were evaluated to mitigate non-target catches, especially those concerning bark beetles' natural enemies. Materials and Methods: A total of 25 bark-beetle slot traps were placed about $75 \mathrm{~m}$ apart in a pine stand infested by $I$. sexdentatus. Traps were baited with I. sexdentatus aggregation pheromone, whose main components are ipsenol, ipsdienol, and 2-methyl-3-buten-2-ol. Catches were collected every 10 days from March to December. In 2019, 13 traps were modified by applying a 6-mm mesh screen on top of the collection container and by providing three $60 \mathrm{~mm} \times 8 \mathrm{~mm}$ escape windows immediately above the screen. These "modified traps" and their captures were considered separately from the 12 remaining "standard traps." All bark beetle species were recorded, as well as all beetle species $>8 \mathrm{~mm}$. Results: Overall, target catches amounted for $<10 \%$ of the total beetle catches. The most-collected species was the bark beetle Orthotomicus erosus Wollaston. Trap modification allowed the escape of larger species, resulting in the reduction of the average size of caught specimens. Even though non-target catches among predators were still high, the proportion of major predators (T. formicarius and T. caerulea) to bark beetles showed a statistically significant reduction of predator catches in modified traps, an encouraging outcome. Conclusions: Trap modifications may mitigate the problem of non-target catches during mass trapping, especially reducing catches of beetle species larger than the target. However, the key is to schedule mass trapping only during those seasons when the target adults are more active than the main predator adults, thus limiting their catches and, consequently, the negative effects on pest management and biodiversity.
\end{abstract}

Keywords: bark beetles; natural enemies; aggregation pheromones; pest management; Mediterranean pine forests

\section{Introduction}

Due to favorable conditions, bark beetle outbreaks are alarmingly increasing, with a severe impact on European conifer forests [1-3]. In recent years, climate change has caused a higher frequency of extreme weather events, including windstorms and severe drought [1]. These disturbances increase the suitable breeding materials for bark beetles, such as stressed or uprooted trees [1]. Therefore, bark beetle population densities may 
rise and, during epidemic outbreaks, aggressive bark beetle species are able to move from stressed and weakened trees to healthy ones; this behavior was confirmed in the six-toothed pine bark beetle, Ips sexdentatus (Böerner) (Coleoptera: Curculionidae: Scolytinae) [4].

I. sexdentatus occurs in pine forests throughout the Eurasian continent. It is generally considered a secondary pest [5] and less aggressive than the congeneric I. typographus (Linnaeus) [6], but sometimes it can become a more serious pest. For example, in Italy this bark beetle has recently been favored by the exotic scale Matsucoccus feytaudi Ducasse, which causes the decline of the maritime pine (Pinus pinaster Aiton) forests. In the suitable climatic conditions of Southern Europe, with large availability of suitable hosts (the stressed maritime pines), I. sexdentatus populations have rapidly increased. Under these conditions, their attacks also involve healthy trees of other pine species [7-9]. Coastal pine forests are particularly important in Italy, as they provide numerous goods and services, especially for recreational tourism [10]; thus, protecting these forests is essential to maintaining their social, environmental, and economic functions.

Only a few direct control measures are available to contain bark beetle populations: prompt cutting of infested trees, trap-trees, trap-logs, and pheromone-baited masstrapping [11]. Though it is generally carried out in combination with the prompt cutting of infested trees, mass-trapping is essential, particularly when phytosanitary felling cannot be swiftly carried out [12]. Several studies report the efficacy of mass-trapping in bark beetle control, alone or in combination with other measures [13-17]. However, its effectiveness is still controversial, as it is not easy to prove in terms of real tree mortality reduction, particularly since other biotic and abiotic factors can affect the results [16,17].

Mass-trapping, however, may lead to significant negative effects. Indeed, many studies show its negative impact on non-target insect species, which may also be lured by the pheromone baits [18-20]. Among non-target catches, predators are of particular concern $[18,19]$. Bark beetle natural enemies track their prey using aggregation pheromones as kairomones; thus, they too may be attracted by pheromone traps [21,22]. Two of the main natural enemies of bark beetles, Thanasimus formicarius (L.) (Coleoptera: Cleridae) and Temnoscheila caerulea (Olivier) (Coleoptera: Trogossitidae), are frequently captured in high numbers in I. sexdentatus pheromone traps $[9,19,20,23,24]$. Furthermore, other saproxylic insects that exploit the same pheromones to locate suitable host plants (typically weakened by the target bark beetle species) may also be caught during mass-trapping programs [19]. Thus, non-target catches may negatively affect the natural regulation of bark beetle populations, as well as the conservation of other saproxylic species [19].

Several studies focus on the development of more selective trapping techniques to mitigate these negative effects $[8,9,20]$. For example, mass-trapping selectiveness could be improved by finding the best component blends. Although bark beetles' natural enemies often use their prey's pheromones to track them [22], prey and predators may have different preferences in terms of optical isomers or other specific pheromone components [25-27] that can be exploited to reduce predator catches [18]. In regards to I. sexdentatus, Etxebeste et al. [8] determined that the composition of non-target catches associated with this species varied greatly with different pheromone blends. A reduction in mass-trapping negative effects can also be achieved by choosing the right type of trap. Martin et al. [9], for instance, found that slot traps are more selective than multi-funnel traps, showing fewer predator catches, particularly favoring the escape of T. formicarius. Finally, traps can be modified to prevent non-target beetles from entering, especially those bark beetle predators that are larger than their prey. Martin et al. [9] and Ross and Daterman [28] assessed how modifying multiple-funnel traps and slot traps by adding a 6-mm mesh screen and by opening escape windows may help to limit predator catches. In this study, non-target beetle catches were recorded during a mass-trapping program in a pine forest in Tuscany (Italy); trap modifications similar to those used by Martín et al. [9] were evaluated. 


\section{Materials and Methods}

\subsection{Study Area and Sampling Design}

The present study was carried out during 2016-2019 in a Tuscan coastal pine stand, approximately 70 hectares, between Marina di Grosseto and Principina a Mare, in the Province of Grosseto (Italy) $\left(42^{\circ} 42^{\prime} 17.22^{\prime \prime} \mathrm{N}, 10^{\circ} 59^{\prime} 47.59^{\prime \prime} \mathrm{E}\right)$. This private forest plot was mainly composed of P. pinaster, with a small amount of stone pine (Pinus pinea L.); here, since 2006, the former species has been gradually infested by M. feytaudi, which has caused serious damages and has stressed the trees. Since 2014, the huge availability of weakened pines caused a high increase in the population density of I. sexdentatus. Another aggressive bark beetle species, Tomicus destruens (Wollaston), was also present in this stand and contributed to pine mortality. In addition, the bark beetle Orthotomicus erosus Wollaston was abundant, although it was mostly found on pines already infested by I. sexdentatus or T. destruens, and/or highly stressed by abiotic factors. This area has a high touristic value due to its many campsites; therefore, to reduce the population density of I. sexdentatus and the number of attacked pines, prompt cutting of infested trees, as well as mass-trapping were carried out. On 28 April 2016, a total of 25 Super Forest bark beetle slot traps (Serbios s.r.l., Badia Polesine, Rovigo, Italy) were placed in the pine stand along the south-western borders of the forest plot, spacing each trap by about $75 \mathrm{~m}$ (Figure 1). This pattern addressed the higher I. sexdentatus infestation in the pine stand closer to the coastline-and outside our study area-where no control measures were carried out. Super Forest traps are a variant of the common Theysohn design, with fewer, longer slots, but with the same amount of slot rows (seven) (Figure 2A). Traps were baited with the commercial blend of the I. sexdentatus aggregation pheromone manufactured by Serbios s.r.l., whose main compounds are ipsenol, ipsdienol, and 2-methyl-3-buten-2-ol. Catches were collected every 10 days from March (except in 2016 when traps were installed in April) to December. Bait was renewed every 30-50 days, according to the dispensers' lifespan (as indicated by the manufacturer) and to the weather conditions in the study area, since warmer climates of Tuscany deplete these dispensers considerably faster during summer months [29]. Thus, sticking to manufacturer instructions would lead to errors in interpreting flight patterns. In order to ensure a continuous presence of adequately baited traps in the field, a baiting rotation system based on alternating pairs was set up: group A consisted of six pairs plus the 25th trap; group B included the remaining six pairs (Figure 1). The two groups were baited 20 days apart, always following the same renewal schedule based on the dispensers' lifespan and on weather conditions.

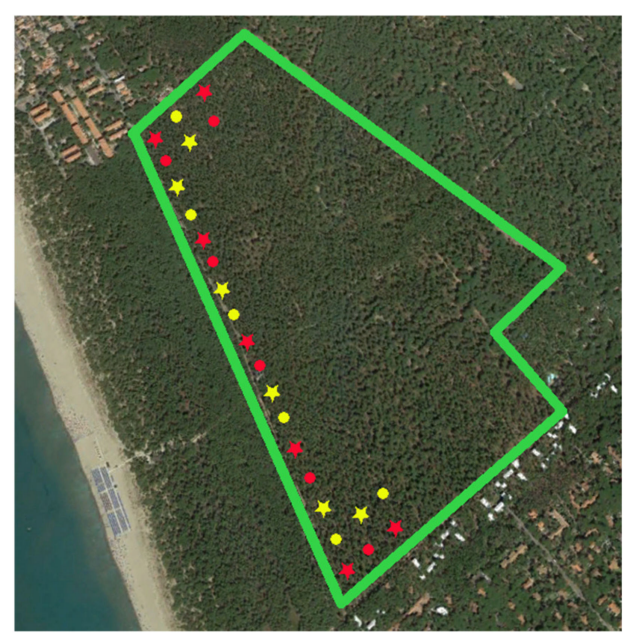

Figure 1. Study area with trap pattern as applied in 2019. Part of the coastal pine stands in the Municipality of Grosseto (Tuscany, Italy) is shown; the green line delimits the study area's borders. Bait rotation alternated groups A (in red) and B (in yellow; symbols indicate modified (stars) and standard (circles) traps. 


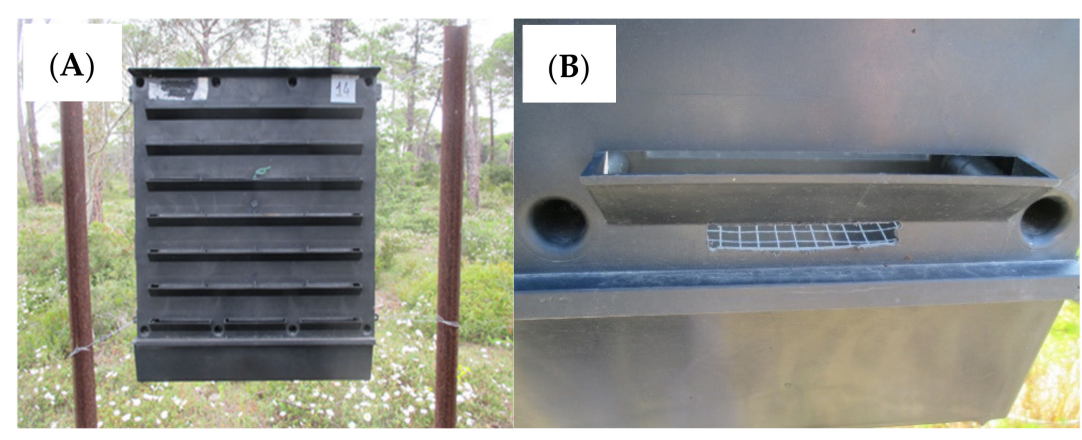

Figure 2. Standard trap without modifications (A) and detail of a modified trap (B): through one of the three escape windows the $6 \mathrm{~mm}$ mesh screen can be seen inside.

Besides the target beetle, in the first three years of the study (2016-2018), special attention was reserved for some of the other beetles trapped: the major non-target bark beetles and the two major bark beetle predators, T. formicarius and T. caerulea. In 2019, additional non-target beetles were considered, we grouped them into two categories according to their mean length: (1) all bark beetles; and (2) all beetles on average $>8 \mathrm{~mm}$, among which T. caerulea and T. formicarius were grouped. In this year, 13 traps were modified by applying a 6-mm mesh screen on top of the collection container as in Martìn et al. [9], and by providing three additional $60 \mathrm{~mm} \times 8 \mathrm{~mm}$ escape windows immediately above the mesh screen (one central window on one side and two lateral windows on the other side) (Figure 2B). These traps were called "modified traps" and their captures were considered separately than those from the "standard traps," which were not modified. "Modified traps" were evenly distributed in the bait renewal rotation by alternating them with "standard traps." Finally, a random sub-sample of 30 specimens per each species (when possible) per each kind of trap (modified or standard) was measured, recording their body length.

\subsection{Statistical Analysis}

The analysis of variance (ANOVA) for repeated measures (catches in the same trap on different dates were considered repeated measures) was used to compare catches in standard traps and modified traps of (1) I. sexdentatus; (2) non-target bark beetles (all species together); (3) all bark beetles together; (4) beetles $>8 \mathrm{~mm}$; and finally (5) species of this last category, with enough catches (more than 30 ), were analyzed separately. All the data analyzed with ANOVA were log transformed. Simpson's index was used to compare species diversity in the two kinds of traps employed in 2019. As regards the two main predators, T. caerulea and T. formicarius, the 2019 mean catches, separated according to the kind of trap, were then compared with ANOVA with those of previous years when the traps had not yet been modified but were in the same positions. Pearson correlation was applied to assess the correlation between the main predators and bark beetle catches. In addition, the percentages of these two predators were compared using the chi square test, taking into account the total bark beetles and predators caught by standard and modified traps. The size of beetles $>8 \mathrm{~mm}$ trapped in 2019 in modified traps were compared with the size of those from standard traps with ANOVA; the same test was separately carried out for those species with enough catches (more than 30 ) in each kind of trap.

\section{Results}

\subsection{Catches in I. sexdentatus Pheromone Traps}

During the first three years of the study (2016-2018), 42,823 I. sexdentatus adults were caught in pheromone traps (Table 1). However, these were not the most numerous catches; in fact, I. sexdentatus was less than a tenth compared to the non-target beetle species. The most-trapped beetles (469,545 specimens) were non-target bark beetles (Table 1): O. erosus, Hylurgus ligniperda (Fabr.), and T. destruens. While only few T. destruens specimens were caught (62 in total in the three years), the other two species were trapped frequently and in great numbers. More specifically, O. erosus was the most-caught species in the first 
three-year period, with 452,756 individuals, which represented almost $95 \%$ of all beetles snared. Among the non-target beetles were two of the bark beetles' major predators: $T$. caerulea and T. formicarius; each year more than 2000 specimens were caught, with a total of 7500 in the three years. The predator/prey (I. sexdentatus) ratios for T. formicarius were 0.13 , 0.12 and 0.08 in 2016, 2017, and 2018 respectively, while for T. caerulea they were $0.09,0.05$, 0.07. Finally, other beetles, larger than bark beetles, were also captured, but these were neither identified nor counted in the first three years of the study.

Table 1. Total number of beetles trapped with the Ips sexdentatus aggregation pheromone during the 2016-2018 period in the study site (Municipality of Grosseto, Tuscany, Italy).

\begin{tabular}{cccccccc}
\hline \multirow{2}{*}{ Year } & \multirow{2}{*}{ I. sexdentatus } & \multicolumn{3}{c}{ Non-Target Beetles } & \multicolumn{2}{c}{ Predator/Prey Ratios } \\
\cline { 3 - 7 } & & Other Bark Beetles & T.formicarius & T. caerulea & Total & T. formicarius & T. caerulea \\
\hline 2016 & 11,042 & 231,284 & 1447 & 1013 & 233,744 & 0.13 & 0.09 \\
2017 & 12,774 & 120,574 & 1587 & 621 & 122,782 & 0.12 & 0.05 \\
2018 & 19,007 & 117,687 & 1450 & 1382 & 120,519 & 0.08 & 0.07 \\
\hline \multirow{2}{*}{ Total } & 42,823 & 469,545 & 4484 & 3016 & 477,045 & \\
\hline
\end{tabular}

During 2019, the last year of the study, 182,641 specimens were caught across both types of traps; this tally takes into account only the species that had been counted during the first three-year period (I. sexdentatus, T. formicarius, T. caerulea, and other bark beetles). Again, the great majority were non-target bark beetles $(170,219)$ (Table 2): about $98 \%$ of these trapped beetles were $O$. erosus, which was the most captured species, with 167,773 individuals; as regards the other bark beetles, 1855 adults of H. ligniperda and one T. destruens were recorded. Besides these main species, other minor bark beetles were recorded with a total of 590 specimens: Carphoborus pini Eichhoff (33), Coccotrypes dactyliperda Fabricius (8), Crypturgus mediterraneus Eichhoff (31), Crypturgus pusillus Gyllenhal (143), Hylurgus micklitzi Wachtl (97), Pityogenes bidentatus Herbst (251), Pityophthorus pubescens Marsham (21), and Xylocleptes biuncus Reitter (6). Again, the two most important predator species, T. caerulea (2409) and T. formicarius (925), were trapped. The predator/prey ratios calculated on standard traps were 0.13 for T. formicarius and 0.33 for T. caerulea. In 2019, however, other large non-target beetles were also taken into account, for a total of 1,662 recorded specimens. This group included specimens from five different families: Melolonthidae, with one species, Amadotrogus grassii (Mainardi) (112); Elateridae, with two species, Lacon punctatus (Herbst) (191) and Melanotus (Melanotus) crassicollis (Erichson) (342); Buprestidae, with two species, Buprestis (Buprestis) novemmaculata Linnaeus (92), and Chalcophora detrita (Klug) (5); Cerambycidae, with three species Monochamus galloprovincialis (Olivier) (8), Acanthocinus griseus (Fabricius) (838), Oxypleurus nodieri Mulsant (3), and finally Curculionidae not in the sub-family of Scolytinae, with one species, Brachyderes (Brachyderes) incanus (Linnaeus) (71).

Table 2. Number of beetles trapped with the Ips sexdentatus aggregation pheromone during 2019 in the study site (Municipality of Grosseto, Tuscany, Italy) with standard and modified slot traps.

\begin{tabular}{|c|c|c|c|c|c|c|c|}
\hline \multirow{3}{*}{ Type of Trap } & \multirow{3}{*}{ N. of Traps } & \multirow{3}{*}{ I. sexdentatus } & \multicolumn{5}{|c|}{ Non-Target Beetles } \\
\hline & & & \multirow{2}{*}{ Other Bark Beetles } & \multicolumn{3}{|c|}{ Larger Beetles } & \multirow{2}{*}{ Total } \\
\hline & & & & T. formicarius & T. caerulea & Others & \\
\hline Standard & 12 & 3982 & 53,622 & 505 & 1333 & 1392 & 56,852 \\
\hline Modified & 13 & 5106 & 116,597 & 420 & 1076 & 270 & 118,362 \\
\hline Total & 25 & 9088 & 170,219 & 925 & 2409 & 1662 & 175,214 \\
\hline
\end{tabular}

Catches of target and non-target beetles were differently distributed during the year. I. sexdentatus adults in 2016, 2017, and 2018 had three peaks in activity: spring (March/April) (in 2016 this first peak was not noted because traps were deployed later), 
summer (July / August), and particularly autumn (October/November). On the contrary, in 2019 the autumnal catch showed a remarkable drop (Figure 3). The two main I. sexdentatus predators (T. caerulea and T. formicarius), instead, were more active in spring, particularly in April, and summer, while in autumn only a very low number of adults were trapped. In fact, in the spring/summer period during the years 2016/2018, the mean predator/prey ratio was 0.43 , while during the autumn it was 0.03 . This activity distribution was also true for all other non-target beetles trapped. In fact, during the study period non-target bark beetles were caught particularly during the spring/summer period, with a non-target/target bark beetle ratio of 21, while during autumn these non-target catches were much lower, plummeting to a ratio of 0.51 . Accordingly, beetles $>8 \mathrm{~mm}$ and non-target bark beetles were caught mainly during the 2019 spring/summer period, while very low catches occurred in the autumn (Figure 4).

\subsection{Standard Traps Versus Modified Traps}

The mean number of I. sexdentatus catches in standard traps was not different when compared to the average catches of $I$. sexdentatus in modified traps (ANOVA, $d f=1$, $F=0.528, p=0.475)$. The mean number of non-target bark beetle catches did not differ between the two types of traps (ANOVA, $d f=1, F=2.325, p=0.141$ ). On the contrary, the mean number of all non-target beetles $>8 \mathrm{~mm}$ was lower in the modified traps (ANOVA, $d f=1, F=27.744, p<0.001)$. In fact, the percentage of all non-target beetles $>8 \mathrm{~mm}$ trapped by the standard traps was $44.79 \%$ of the total $(7,212$ specimens, not including the non-target bark beetles) (Figure 5A), while in the modified ones this percentage dropped to $25.70 \%$ of the total (6871 specimens) (Figure $5 \mathrm{~B}$ ). In addition, the modified traps had a lower species diversity (Simpson's index $=0.56$ ) compared to the standard ones (Simpson's index $=0.75$ ). For 10 out of the 11 species included in the "non-target beetles $>8 \mathrm{~mm}$ ", a decrease in catches was recorded with the modified traps, although this decrease was statistically significant only for seven species: L. punctatus (ANOVA, $d f=1, F=34.181$, $p<0.001$ ), $M$. crassicollis (ANOVA, $d f=1, F=30.968, p<0.001$ ), B. novemmaculata (ANOVA, $d f=1, F=14.493, p<0.01$ ), A. griseus (ANOVA, $d f=1, F=18.985, p<0.001$ ), and B. incanus (ANOVA, $d f=1, F=6.163, p<0.05$ ); both $C$. detrita and $M$. galloprovincialis were caught only in standard traps.

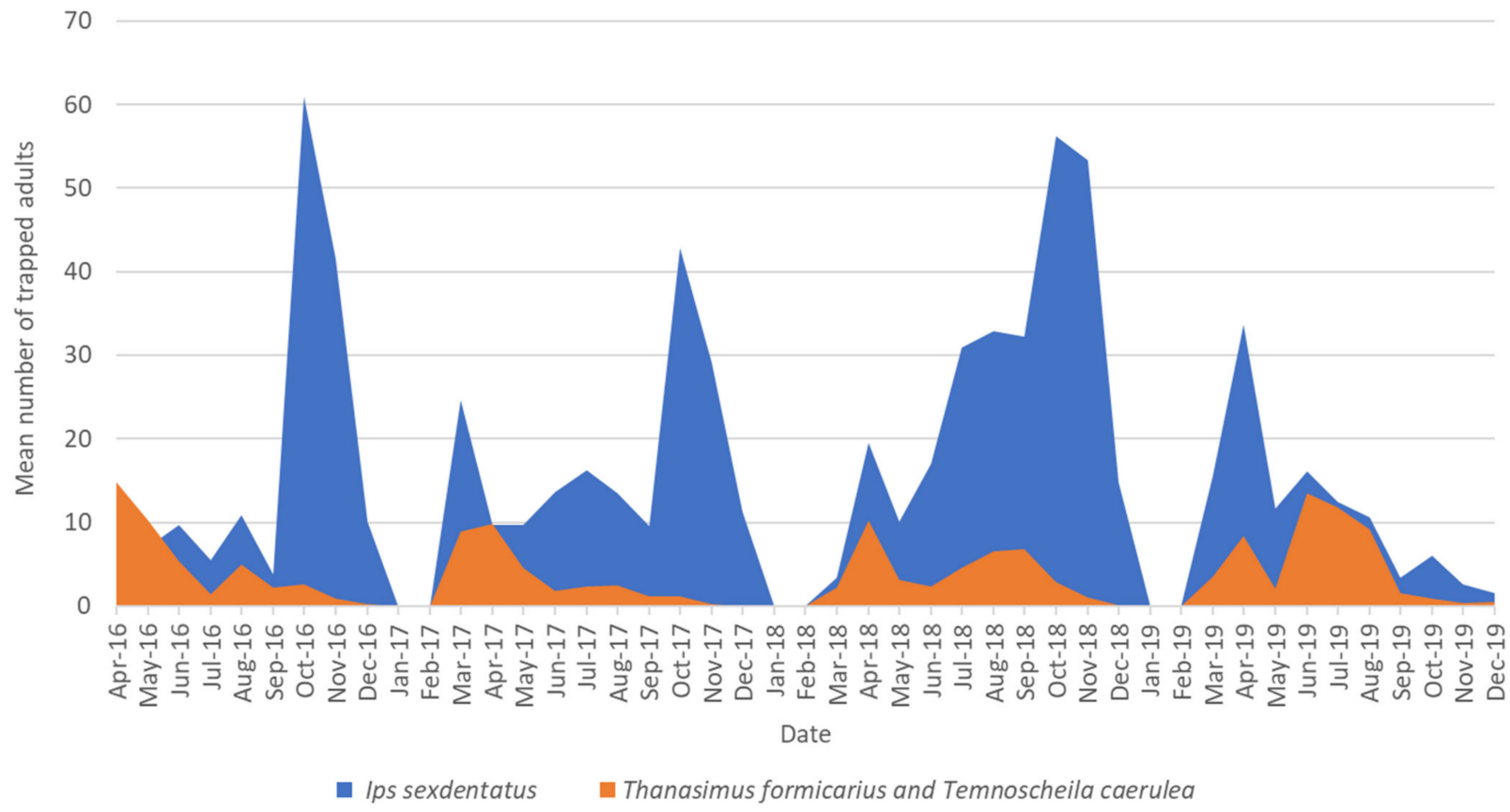

Figure 3. Mean number of trapped adults of Ips sexdentatus and its main predators (Thanasimus formicarius and Temnoscheila caerulea) in the study site (Municipality of Grosseto, Tuscany, Italy) using standard slot traps, from 2016 to 2019. 


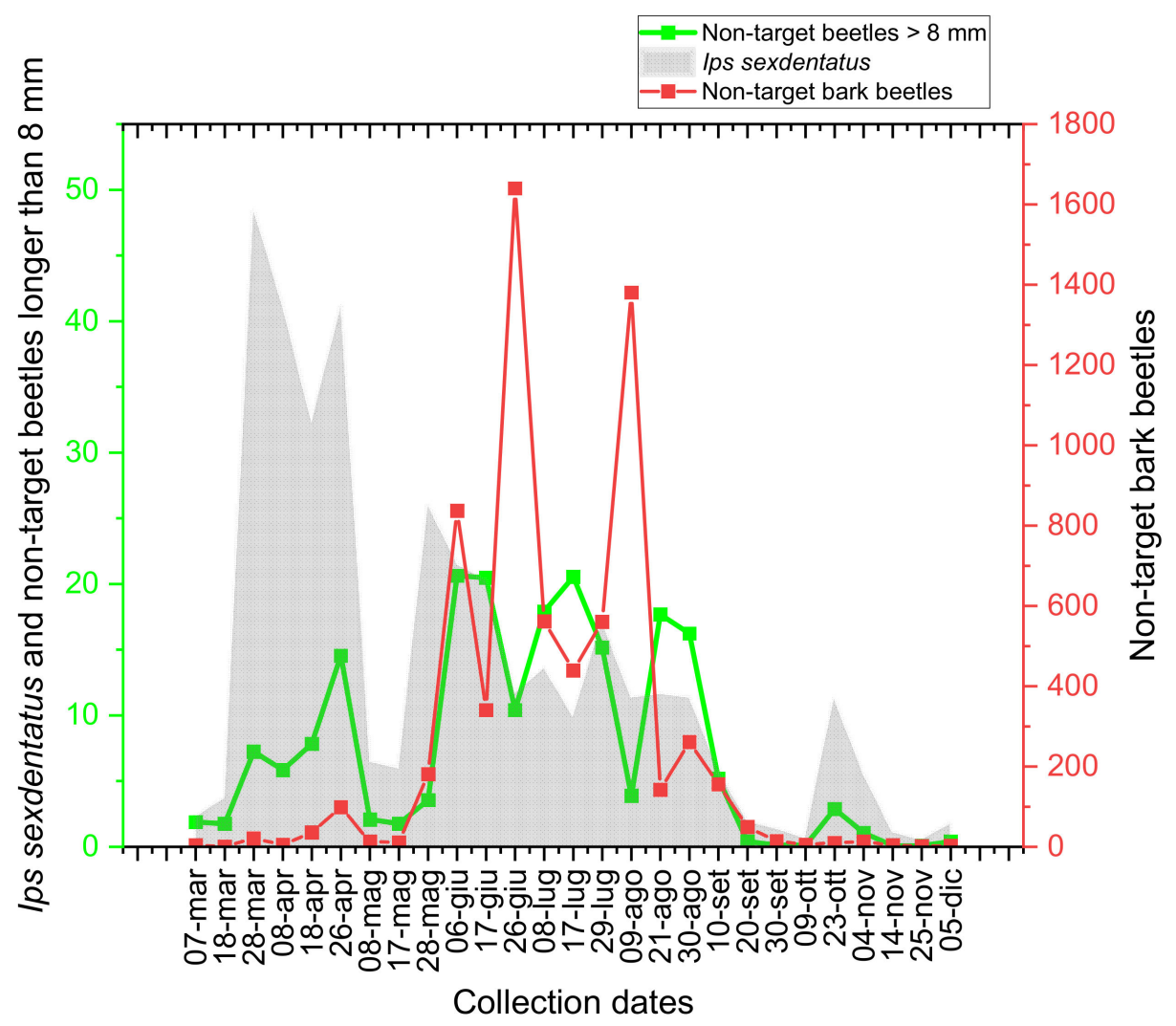

Figure 4. Mean number (standard and modified traps together) of trapped adults of Ips sexdentatus, non-target bark beetles, and non-target beetles $>8 \mathrm{~mm}$ in the study site (Municipality of Grosseto, Tuscany, Italy) during 2019.

A

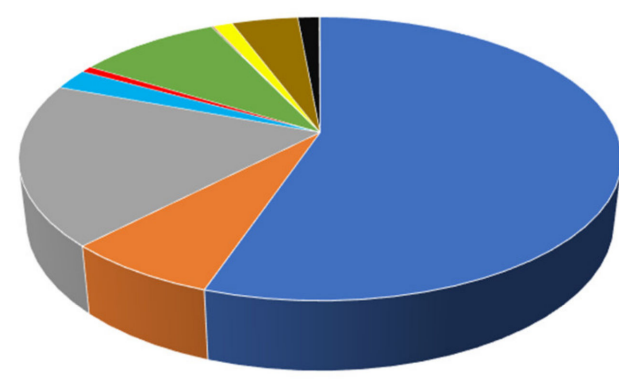

B

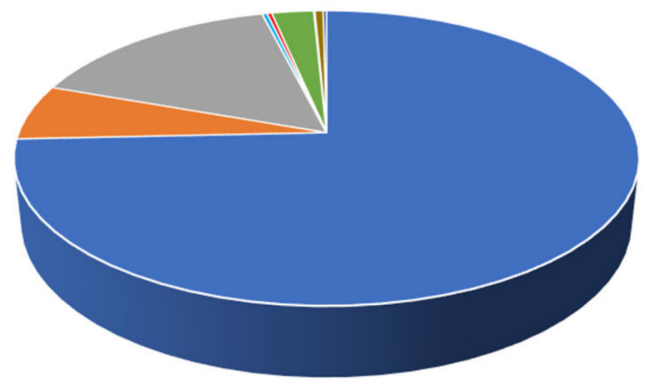

- Ips sexdentatus

- Temnoscheila caerulea

- Brachyderes incanus

- Oxypleurus nodieri

- Buprestis novemmaculata

- Amadotrogus grassii
- Thanasimus formicarius

- Lacon punctatus

- Acanthocinus griseus

- Monochamus galloprovincialis

- Melanotus crassicollis

- Chalcophora detrita

Figure 5. Percentages of I. sexdentatus and non-target beetles $>8 \mathrm{~mm}$ caught in standard traps (A) and modified traps (B) baited with the I. sexdentatus aggregation pheromone in the study site (Municipality of Grosseto, Tuscany, Italy) during 2019.

The two main bark beetle predators were the most-caught species in this category (non-target beetles $>8 \mathrm{~mm}$ ), though the efficacy of modified traps was less evident. Indeed, catches in 2019 in the two types of traps were not statistically different (ANOVA, $d f=1$, 
$F=3.882, p=0.061)$. Furthermore, the predator/prey ratios for $T$. formicarius in standard and modified traps were 0.13 and 0.08 , respectively, while for T. caerulea the predator/prey ratios were 0.33 and 0.21 . Predator (T. formicarius and T. caerulea) catches were positively correlated to bark beetle (I. sexdentatus and non-target bark beetles) catches (Pearson correlation, $r=0.404, p<0.01$ ), while no differences in all bark beetle captures emerged between standard and modified traps (ANOVA, $d f=1, F=2.314, p=0.142$ ). However, the percentage of predators in modified traps (1.22\% of the total bark beetles and predators) was significantly lower than that in standard traps (3.10\%) (Chi square test, $\chi^{2}=790.909$, $p<0.001)$. In addition, considering standard traps throughout the whole study period, the mean number of catches for 2019 were significantly higher than the previous three years' (GLM, Wald Chi-Square $=46,295, p<0.001$ ). In modified traps (in 2016-2018 the same traps, located in the same sites, but not yet modified, were used) there was not a statistically significant difference (Figure 6).

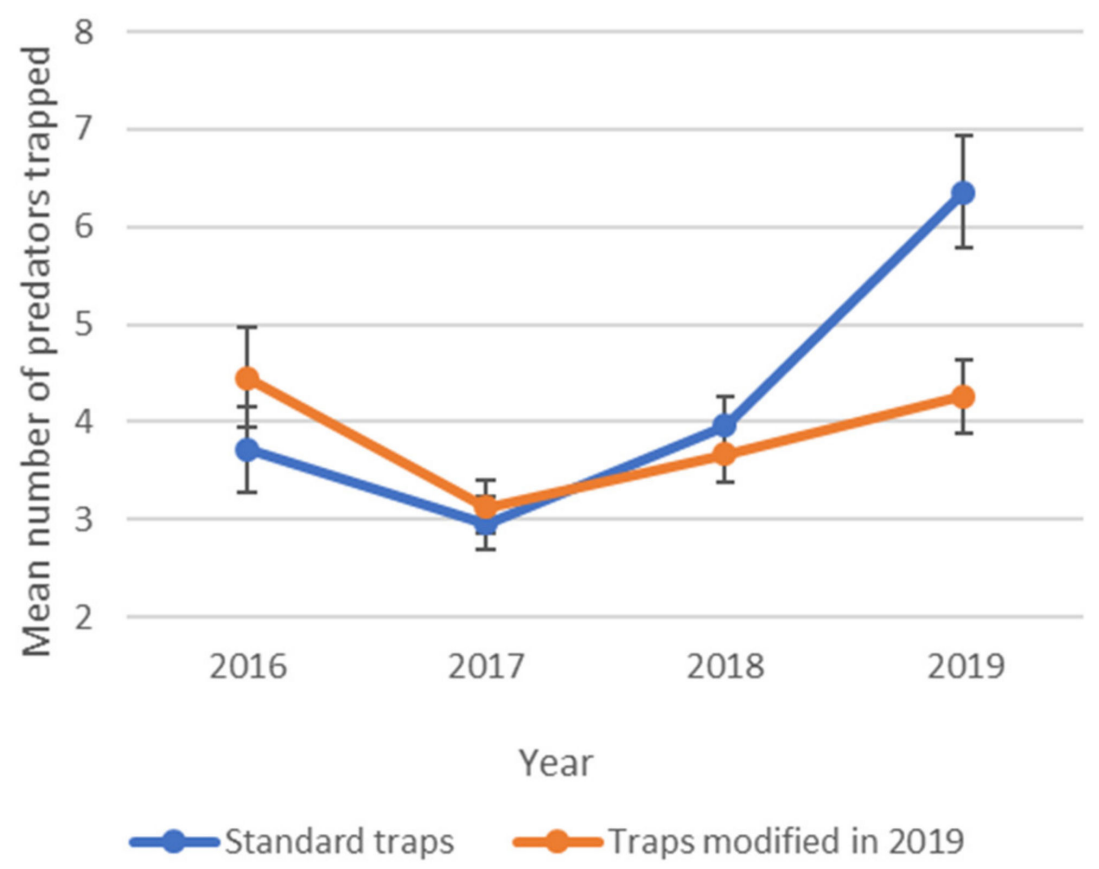

Figure 6. Mean catches per trap per control date of T. caerulea and T. formicarius in standard and modified traps in the study site (Municipality of Grosseto, Tuscany, Italy). Trap modifications were not present until 2019; however, trap position never changed during the four-year study. Bars indicate standard error.

Trap modification favored the larger species (Figure 7); in fact, beetles captured in standard traps had a higher mean size $(14.22 \mathrm{~mm})$ compared to those in the modified traps $(12.14 \mathrm{~mm}$ ) (ANOVA, $d f=1, F=15.014, p<0.001)$. However, $T$. caerulea did not benefit from trap modification despite its size (Figure 7). Comparing the size of trapped specimens of each species in standard and modified traps, a general significant difference was observed: for each species, specimens captured by modified traps were smaller in size (ANOVA, $d f=7, F=14.972, p<0.05)$. However, only in the case of $A$. griseus did this difference end up being statistically significant (Wald Chi square $=8.878, p<0.01$ ). 


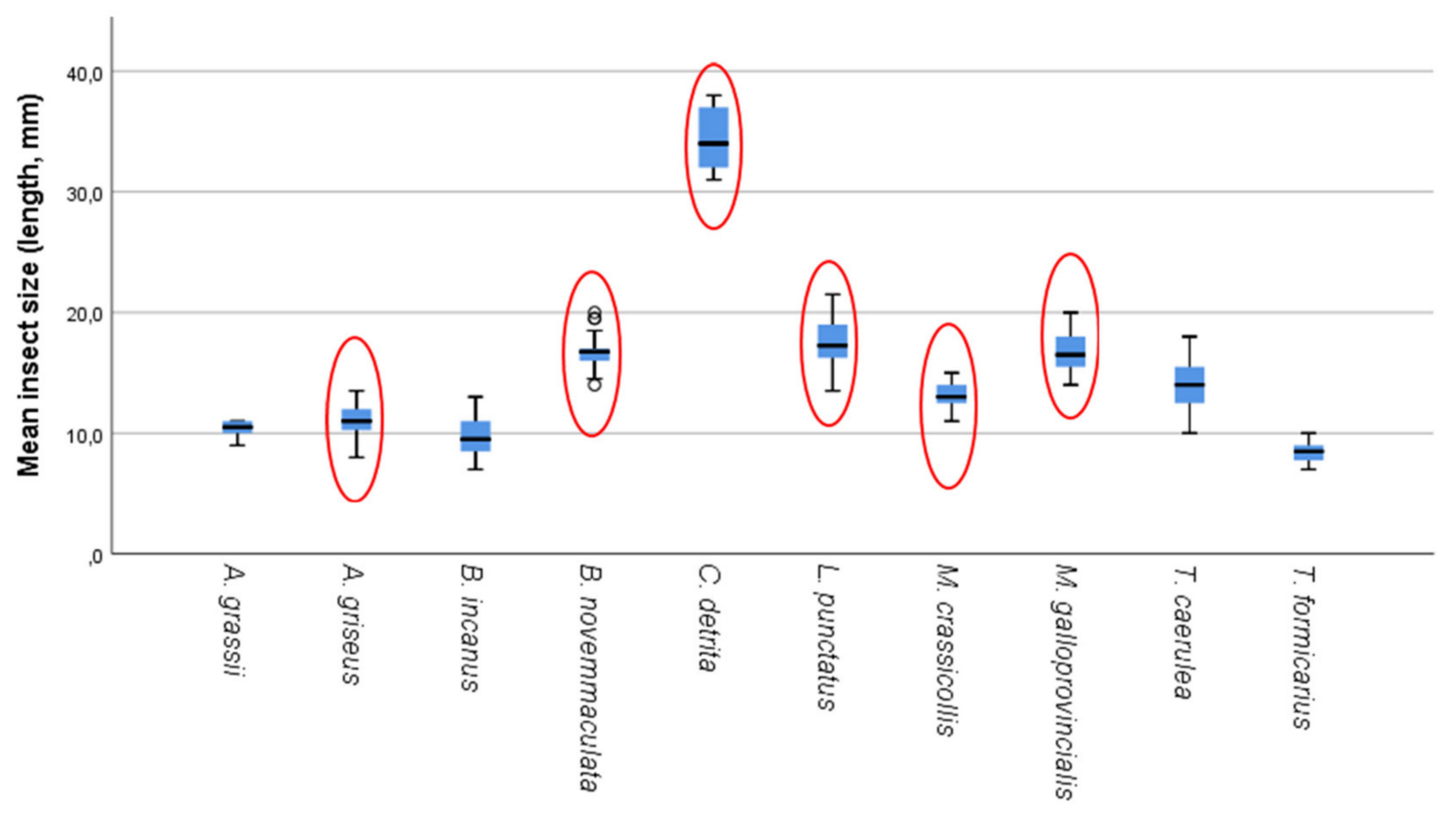

Figure 7. Body length $(\mathrm{mm})$ of the trapped insect species. Red ovals represent species with a subsequent significant catch reduction in modified traps. Bars indicate standard error.

\section{Discussion}

As already assessed in other studies $[19,20]$ I. sexdentatus aggregation pheromone attracts many other saproxylic beetles, among which are several bark beetles receptive to the same pheromonal components [30]. In our study, the most-trapped beetles were $O$. erosus and H. ligniperda, both of which had been shown to be captured when the I. sexdentatus pheromone was used as bait $[8,9,20]$. Furthermore, Serez [31] demonstrated how commercially available pheromones for I. sexdentatus can be used to attract $O$. erosus. The numbers of specimens trapped in our studies were in agreement with the observations of Serez [31] in Turkish areas infested by O. erosus; moreover, O. erosus has been recently confirmed as an increasingly dangerous pest in Mediterranean pine forests [32]. However, in our study area, O. erosus seems less aggressive. In fact, despite the abundant catches and the fact that $O$. erosus is able to kill whole trees, in our study only small pine branches were attacked, while no pines showed large areas of the trunk or of the main branches infested by this species. Interestingly, T. destruens, the other bark beetle which causes serious damage in the study area's pine forest, was trapped only in low numbers (63 specimens total over the four years).

Other saproxylic beetles trapped in I. sexdentatus traps were bark beetles' predators, which can be kairomonally attracted by the bait intended for their prey, as stated by other studies [8,19]. In fact, these species can use aggregation pheromones, together with volatiles, to locate their bark beetle prey [18]. In our study, four predators, T. formicarius, T. caerulea, L. punctatus, and M. crassicollis were trapped. The first three species had already been collected in traps baited with pheromone blends of I. sexdentatus in other studies $[8,19,20,33]$. T. formicarius and T. caerulea are important bark beetle natural enemies that contribute to their population control by preying on their larvae under the bark [9]; thus, catching these predators during mass-trapping constitutes a problem for bark beetle management. Bark beetle control methods must be sustainable, impacting only (or almost only) the target species. In this study, the predator/prey ratios were considerably high compared to other studies [34]. This could cause a boomerang effect, since it was estimated that a reduction of predator densities could lead, within 4-20 bark-beetle generations, to a doubling of the pest population, prolonging bark beetle outbreaks [35]. 
Yet another important consideration is that other saproxylic beetles, including vulnerable species, also locate their plant hosts by exploiting bark beetle pheromones [36]. In our study's catches, almost all beetles $>8 \mathrm{~mm}$ were saproxylic. Among these, we found several vulnerable species: Melolonthidae $A$. grassii is considered rare; one species of Buprestidae, C. detrita, is categorized as "endangered" in the European red list of the Italian saproxylic beetles; and one, Cerambycidae O. nodieri, which is "near threatened" and is also considered a facultative predator of bark beetles [37]; all other species were of lesser concern [38]. Many of the captured species had already been caught in similar studies with traps baited with conifer monoterpenes and/or bark beetle pheromones containing ipsenol and 2-methyl-3-buten-2-ol, or ipsdienol [8,9,19,20,36]. Therefore, besides the problem of predator decline, mass-trapping might reduce the overall biodiversity of saproxylic insects, with even higher impacts on endangered species.

The hypothesis that low I. sexdentatus populations may negatively affect target/nontarget ratios in traps was proposed by Panzavolta et al. [20], who, in their two-year study, observed low population densities and low percentages of the target bark beetle in traps (ranging between $2 \%$ and $35 \%$ ). In the present study, higher averages of I. sexdentatus specimens were caught by pheromone traps, and more severe damage to the pine forest was observed, both indicative signs of a larger population density. In fact, considering only the study period of Panzavolta et al. [20] (from June to the end of I. sexdentatus flight), we trapped a mean of about 492 specimens per trap per year, while in their study only 44.3 and 3.7 mean catches were obtained. However, in the current study, higher I. sexdentatus catches corresponded to higher non-target catches. In fact, during the four years, I. sexdentatus accounted for only $8 \%$ of the total specimens collected in the pheromone traps. Therefore, the low specificity of the pheromone blend used is confirmed, regardless of I. sexdentatus population level.

This study confirmed the effectiveness of the trap modifications proposed by Martín et al. [9] if all saproxylic beetles $>8 \mathrm{~mm}$ were considered together, although modifications applied are still not enough to negate non-target catches of some species taken individually. More specifically, results were not satisfactory for all natural enemies: only for L. punctatus and M. crassicollis was the catch reduction in modified traps significant in comparison with standard traps, while the two main predators T. formicarius and T. caerulea were caught in high numbers in modified traps as well, in agreement with Martin et al. [9]. Traps in our study were also provided with escape windows, not present in the slot traps modified by Martin et al. [9], but this did not lead to fewer catches of this non-target species when compared with their study, as we recorded a ratio of one trapped T. caerulea for every five I. sexdentatus. However, we found that catches of T. formicarius and T. caerulea were positively correlated with those of bark beetles (all trapped species). Probably, as suggested by Bakke and Kvamme [39], predators may be also attracted by already caught bark beetles inside the trap, which may release pheromones with their frass. In fact, some bark beetle species are able to produce pheromones after emergence without feeding, as demonstrated for I. paraconfusus Lanier and I. pini (Say) [40]. In our study, traps with high bark beetle catches resulted uniformly distributed between modified and standard traps (differences in mean catches were not statistically significant). However, if we consider predators in proportion to bark beetles, a statistically significant reduction of predator catches emerged in modified traps, showing an encouraging outcome for trap modifications.

Another important strategy to reduce the impact of mass-trapping on non-target beetle species is to adjust the period of traps set in the field, exploiting the different seasonal abundance of target and non-target beetles. Overall, we observed the lowest non-target catches during autumn, both as regards beetles $>8 \mathrm{~mm}$ long and non-target bark beetles (Figure 4). This is in agreement with other studies that confirmed the lowest flight activity of bark beetles' predators during autumn [20,27], or at least their higher activity during spring $[18,25]$. The highest catches of I. sexdentatus in our study area occurred, on the contrary, in autumn, at least in the 2016-2018 period. This was not confirmed in 2019; however, this was likely due to the phytosanitary felling of numerous attacked pines in the 
study area which was carried out at the end of 2018. As a result, I. sexdentatus population density was reduced, and the study area traits were also modified significantly.

\section{Conclusions}

The results of our study give emphasis to the low specificity of I. sexdentatus aggregation pheromone, as well as its negative effects if used in mass-trapping programs. Slot trap modifications may mitigate the negative effects of mass-trapping on non-target saproxylic beetles, particularly on larger beetles $>8 \mathrm{~mm}$; however, catches of the main bark beetles' predators, T. formicarius and T. caerulea, still remain too high, a negative effect which could escalate in successive generations, leading to a doubling of bark beetle numbers and prolonging outbreaks. Thus, it would be particularly advantageous to exploit the different seasonal abundance of target and non-target beetles particularly in mild areas where the target species' main flight peak occurs in autumn, when other saproxylic species adults are generally less abundant. Therefore, to mitigate the negative effects of I. sexdentatus management on the forest, especially to reduce non-target catches, we recommend choosing slot traps modified with a 6-mm mesh screen and three additional escape windows, as well as concentrating mass-trapping in the autumn.

Author Contributions: Conceptualization and methodology, M.B., F.C., R.T., and T.P.; data curation, M.B., F.C., G.M., E.C., E.P., G.G.; investigation, M.B., F.C., and T.P.; formal analysis, T.P. and M.B.; supervision, T.P.; writing—original draft preparation, T.P.; writing-review and editing, M.B. and T.P. All authors have read and agreed to the published version of the manuscript.

Funding: This research received no external funding.

Data Availability Statement: The data presented in this study are available on request from the corresponding author.

Acknowledgments: We are grateful to the private owners of the pine forest, Società Marinella S.p.A, for their support to the research activities.

Conflicts of Interest: The authors declare no conflict of interest.

\section{References}

1. Hrǒ̌šo, B.; Mezei, P.; Potterf, M.; Majdák, A.; Blaženec, M.; Korolyova, N.; Jakuš, R. Drivers of Spruce Bark Beetle (Ips typographus) infestations on downed trees after severe windthrow. Forests 2020, 11, 1290. [CrossRef]

2. Nikolov, C.; Konôpka, B.; Kajba, M.; Galko, J.; Kunca, A.; Janský, L. Post-disaster forest management and bark beetle outbreak in Tatra National Park, Slovakia. Mt. Res. Dev. 2014, 34, 326-335. [CrossRef]

3. Hlásny, T.; Mátyás, C.; Seidl, R.; Kulla, L.; Merganičová, K.; Trombik, J.; Dobor, L.; Barcza, Z.; Konôpka, B. Climate change increases the drought risk in Central European forests: What are the options for adaptation? For. J. 2014, 60, 5-18. [CrossRef]

4. Rossi, J.P.; Samalens, J.C.; Guyon, D.; van Halder, I.; Jactel, H.; Menassieu, P.; Piou, D. Multiscale spatial variation of the bark beetle Ips sexdentatus damage in a pine plantation forest (Landes de Gascogne, Southwestern France). For. Ecol. Manag. 2009, 257, 1551-1557. [CrossRef]

5. Romero, S.L.; Ochoa, P.R.; Bilbao, J.C.I.; Lafuente, A.G. Los Escolítidos de las Conifferas del País Vasco: Guía Práctica Para su Identificación y Control, 1st ed.; Servicio Central de Publicaciones del Gobierno Vasco: Vitoria-Gasteiz, Spain, 2007; pp. 136-139. ISBN 9788445726501.

6. Eppo Global Databae. Available online: https://gd.eppo.int/taxon/IPSXSE/documents (accessed on 10 December 2020).

7. Hlásny, T.; Krokene, P.; Liebhold, A.; Montagné-Huck, C.; Müller, J.; Qin, H.; Raffa, K.; Schelhaas, M.-J.; Seidl, R.; Svoboda, M.; et al. Living with Bark Beetles: Impacts, Outlook and Management Options; From Science to Policy 8; European Forest Institute: Joensuu, Finland, 2019; ISBN 9789525980752.

8. Etxebeste, I.; Lencina, J.L.; Pajares, J. Saproxylic community, guild and species responses to varying pheromone components of a pine bark beetle. Bull. Entomol. Res. 2013, 103, 497-510. [CrossRef] [PubMed]

9. Martín, A.; Etxebeste, I.; Pérez, G.; Álvarez, G.; Sánchez, E.; Pajares, J. Modified pheromone traps help reduce bycatch of bark-beetle natural enemies. Agric. For. Entomol. 2013, 15, 86-97. [CrossRef]

10. Del Perugia, B.; Travaglini, D.; Bottalico, F.; Nocentini, S.; Rossi, P.; Salbitano, F.; Sanesi, G. Are Italian stone pine forests (Pinus pinea L.) an endangered coastal landscape? A case study in Tuscany. L'Italia For. E Mont. 2017, 72, 103-121. [CrossRef]

11. Fettig, C.J.; Hilszczański, J. Management strategies for bark beetles in conifer forests. In Bark Beetles: Biology and Ecology of Native and Invasive Species, 1st ed.; Vega, F.E., Hofstetter, R.W., Eds.; Academic Press: London, UK, 2015; pp. 555-584. 
12. Gregoire, J.C.; Raty, L.; Drumont, A.; de Windt, N. Pheromone mass trapping: Does it protect windfalls from attack by Ips typographus L. (Coleoptera: Scolytidae)? In Proceedings of the "Integrating cultural tactics into the management of bark beetle and reforestation pests", Vallombrosa, Italy, 1-3 September 1996; Gen. Tech. Rep. NE-236. U.S. Department of Agriculture, Forest Service, Northeastern Forest Experiment Station: Radnor, PA, USA, 1997; pp. 1-8. [CrossRef]

13. Vité, J.P. The European struggle to control Ips typographus-past, present and future. Ecography 1989, 12, 520-525. [CrossRef]

14. Niemeyer, H. Monitoring Ips typographus and Pityogenes chalcographus (Col., Scolytidae) in Lower Saxony and Schleswig-Holstein. J. Appl. Entomol. 1992, 114, 98-102. [CrossRef]

15. Jakuš, R. A method for the protection of spruce stands against Ips typographus by the use of barriers of pheromone traps in north-eastern Slovakia. Anz. Schadlingskd. Pfl. 1998, 71, 152-158. [CrossRef]

16. Schlyter, F.; Zhang, Q.H.; Liu, G.T.; Ji, L.Z. A successful case of pheromone mass trapping of the bark beetle Ips duplicatus in a forest island, analysed by 20-year time-series data. Integr. Pest Manag. Rev. 2001, 6, 185-196. [CrossRef]

17. Faccoli, M.; Stergulc, F. Damage reduction and performance of mass trapping devices for forest protection against the spruce bark beetle, Ips typographus (Coleoptera Curculionidae Scolytinae). Ann. For. Sci. 2008, 65, 309. [CrossRef]

18. Aukema, B.H.; Dahlsten, D.L.; Raffa, K.F. Exploiting behavioral disparities among predators and prey to selectively remove pests: Maximizing the ratio of bark beetles to predators removed during semiochemieally based trap-out. Environ. Entomol. 2000, 29, 651-660. [CrossRef]

19. Etxebeste, I.; Álvarez, G.; Pérez, G.; Pajares, J.A. Field response of the six-toothed pine bark beetle, Ips sexdentatus (Col.: Curculionidae, Scolytinae), to pheromonal blend candidates. J. Appl. Entomol. 2012, 136, 431-444. [CrossRef]

20. Panzavolta, T.; Bracalini, M.; Bonuomo, L.; Croci, F.; Tiberi, R. Field response of non-target beetles to Ips sexdentatus aggregation pheromone and pine volatiles. J. Appl. Entomol. 2014, 138. [CrossRef]

21. Raffa, K.F. Mixed messages across multiple trophic levels: The ecology of bark beetle chemical communication systems. Chemoecology 2001, 11, 49-65. [CrossRef]

22. Wood, D.L. The role of pheromones, kairomones, and allomones in the host selection and colonization behavior of bark beetles. Annu. Rev. Entomol. 1982, 27, 411-446. [CrossRef]

23. Ozcan, G.E.; Eroglu, M.; Akinci, H.A. Use of pheromone-baited traps for monitoring Ips sexdentatus (Boerner) (Coleoptera: Curculionidae) in oriental spruce stands. African J. Biotechnol. 2011, 10, 16351-16360. [CrossRef]

24. Pajares, J.A.; Ibeas, F.; Díez, J.J.; Gallego, D. Attractive reponses by Monochamus galloprovincialis (Col., Cerambycidae) to host and bark bettle semiochemicals. J. Appl. Entomol. 2004, 128, 633-638. [CrossRef]

25. Aukema, B.H.; Dahlsten, D.L.; Raffa, K.F. Improved population monitoring of bark beetles and predators by incorporating disparate behavioral responses to semiochemicals. Environ. Entomol. 2000, 29, 618-629. [CrossRef]

26. Zhou, J.; Ross, D.W.; Niwa, C.G. Kairomonal response of Thanasimus undatulus, Enoclerus sphegeus (Coleoptera: Cleridae), and Temnochila chlorodia (Coleoptera: Trogositidae) to bark beetle semiochemicals in Eastern Oregon. Environ. Entomol. 2001, 30, 993-998. [CrossRef]

27. Williams, K.K.; McMillin, J.D.; Degomez, T.E. Relative and seasonal abundance of three bark beetle predators (Coleoptera: Trogositidae, Cleridae) Across an elevation gradient in ponderosa pine forests of North Central Arizona. West. North Am. Nat. 2009, 69, 351-363. [CrossRef]

28. Ross, D.W.; Daterman, G.E. Pheromone-Baited Traps for Dendroctonus pseudotsugae (Coleoptera: Scolytidae): Influence of selected release rates and trap designs. J. Econ. Entomol. 1998, 91, 500-506. [CrossRef]

29. Bracalini, M.; Croci, F.; Tiberi, R.; Panzavolta, T. Studying Ips sexdentatus (Börner) outbreaks in Italian coastal pine stands: Technical issues behind trapping in warmer climates. In Proceedings of the XI European Congress of Entomology, Naples, Italy, 2-6 July 2018; p. 171.

30. Seybold, S.J.; Huber, D.P.W.; Lee, J.C.; Graves, A.D.; Bohlmann, J. Pine monoterpenes and pine bark beetles: A marriage of convenience for defense and chemical communication. Phytochem. Rev. 2006, 5, 143-178. [CrossRef]

31. Serez, M. Verwendung des Aggregationspheromon-Präparats “Ipslure" gegen den mediterranen Kiefernborkenkäfer, Ips (Orthotomicus) erosus (Woll.) (Col., Scolytidae). Schadlingskd. Pfl. 1987, 60, 94-95. [CrossRef]

32. Pernek, M.; Lacković, N.; Lukić, I.; Zorić, N.; Matošević, D. Outbreak of Orthotomicus erosus (Coleoptera, Curculionidae) on Aleppo pine in the Mediterranean region in Croatia. South East Eur. For. 2019, 10, 19-27. [CrossRef]

33. Larrañaga, I.E.; Hernández, A.B.M.; Escolar, G.P.; Fernández, M.F.; Casero, J.J.D.; Alonso, J.A.P. Evaluación de compuestos semioquímicos para su empleo en estrategias de aumento de enemigos naturales de Ips sexdentatus (Col.: Scolytidae). Cuad. Soc. Esp. Cienc. Forestales 2008, 32, 27-32.

34. Warzeè, N.; Gilbert, M.; Grégoire, J.-C. Predator/prey ratios: A measure of bark-beetle population status influenced by stand composition in different French stands after the 1999 storms. Ann. For. Sci. 2006, 63, 301-308. [CrossRef]

35. Krista, L.; Ryall, L.F. Habitat loss decreases predator-prey ratios in a pine-bark beetle system. Oikos 2005, 110, 265-270.

36. Allison, J.D.; Borden, J.H.; Seybold, S.J. A review of the chemical ecology of the Cerambycidae (Coleoptera). Chemoecology 2004, 14, 123-150. [CrossRef]

37. Gallego, D.; Galián, J.; Diez, J.J.; Pajares, J.A. Kairomonal responses of Tomicus destruens (Col., Scolytidae) to host volatiles $\alpha$-pinene and ethanol. J. Appl. Entomol. 2008, 132, 654-662. [CrossRef] 
38. Audisio, P.; Baviera, C.; Carpaneto, G.M.; Biscaccianti, A.B.; Battistoni, A.; Teofili, C.; Rondini, C. Lista Rossa IUCN dei Coleotteri Saproxilici Italiani, 1st ed.; Comitato Italiano IUCN e Ministero dell'Ambiente e della Tutela del Territorio e del Mare: Rome, Italy, 2014.

39. Bakke, A.; Kvamme, T. Kairomone response in Thanasimus predators to pheromone components of Ips typographus. J. Chem. Ecol. 1981, 7, 305-312. [CrossRef] [PubMed]

40. Seybold, S.J.; Quilici, D.R.; Tillman, J.A.; Vanderwelt, D.; Wood, D.L.; Blomquist, G.J. De novo biosynthesis of the aggregation pheromone components ipsenol and ipsdienol by the pine bark beetles Ips paraconfusus Lanier and Ips pini (Say) (Coleoptera: Scolytidae). Proc. Natl. Acad. Sci. USA 1995, 92, 8393-8397. [CrossRef] [PubMed] 